\title{
CHANGES IN THE ASCORBATE-GLUTATHIONE SYSTEM DURING STORAGE OF RECALCITRANT SEEDS OF ACER SACCHARINUM L.
}

\author{
EWELINA RatajCZAK, STANiSŁaWA PUKACKA \\ Institute of Dendrology Polish Academy of Sciences \\ Parkowa 5, 62-035 Kórnik, Poland \\ e-mail: ewelinaratajczak@tlen.pl
}

(Received: May 12, 2005. Accepted: July 28, 2005)

\begin{abstract}
Two seed lots of Acer saccharinum (recalcitrant), with an initial moisture content of $50 \%$ and $55 \%$, were stored at $+3{ }^{\circ} \mathrm{C}$ for 6 months. After this time, their viability (measured as germinability) reached $100 \%$ and 30\%, respectively. In embryo axes and cotyledons extracted from seeds, two major low molecular antioxidants were assayed: ascorbate (ASA and DHA) and glutathione (GSH and GSSG); and activities of enzymes of the ascorbateglutathione cycle were measured: ascorbate peroxidase (APO) (E.C. 1.11.1.11), monodehydroascorbate reductase (MR) (E.C. 1.6.5.4), dehydroascorbate reductase (DHAR) (E.C. 1.8.5.1), and glutathione reductase (GR) (E.C. 1.6.4.2.). GSH and GSSG contents of embryo axes of stored seeds decreased, as compared to the control (fresh, non-stored seeds), but a larger decrease was observed in seeds with $30 \%$ viability. In cotyledons, a particularly high increase in the GSH content in relation to the control was observed in seeds with $100 \%$ viability, while the GSSG content was significantly lower in both stored seed lots than in the control. The ASA level was twice as high in seeds with $30 \%$ viability as in the control, both in embryo axes and in cotyledons. The activity of enzymes of the ascorbate-glutathione cycle was higher in embryo axes than in cotyledons. In embryo axes of seeds with $100 \%$ viability, enzyme activities were slightly lower than in the control, while in those of seeds with $30 \%$ viability, their activities were higher than in the control. The observed changes in activities of enzymes of the ascorbate-glutathione cycle and in ascorbate and glutathione levels suggest that the stored seeds of $A$. saccharinum have an active antioxidant system, which plays an important role in maintaining their viability during storage.
\end{abstract}

KEY WORDS: ascorbate peroxidase, dehydroascorbate reductase, gluthatione, reductase, monodehydroascorbate reductase, recalcitrant, storage.

\section{INTRODUCTION}

Seeds of Acer saccharinum are a classic example of recalcitrant seeds, i.e. they cannot be dried below a relatively high threshold level of moisture content without a substantial decrease in viability. The seeds can be stored in controlled conditions at $+3^{\circ} \mathrm{C}$ in tightly closed foil bags for few months, although until recently they were believed to remain viable for only up to 2 weeks after collection $(\mathrm{Su}-$ szka et al. 2000).

During storage of recalcitrant seeds, production of reactive oxygen species (ROS) can be enhanced, e.g. of superoxide anion radical $\left(\mathrm{O}^{-}{ }_{2}\right)$, hydrogen peroxide $\left(\mathrm{H}_{2} \mathrm{O}_{2}\right)$, and hydroxyl radical $(\mathrm{OH})$, which may initiate oxidative stress and thus contribute to viability loss (Priestley 1986; Smith and Berjak 1995; Hendry 1993; Walters 1998). ROS are acknowledged as the main factors causing various damages in cells by means of oxidation, as it leads to cell death. The scavenging of free radicals and prevention of potential mo- lecular damages are controlled by the defence mechanisms activated in plant cells. Those mechanisms involve low molecular and enzymatic antioxidants (Bowler et al. 1992; Foyer et al., 1994; Torres et al. 1997; Bailly et al. 1998). The main antioxidants of the water phase are: ascorbate and glutathione. Ascorbic acid (ASA, vitamin C) is present in chloroplasts, vacuoles, mitochondria and the cytosol. Its strong reducing properties determine its antioxidant properties. It reacts with $\mathrm{O}_{2}^{--}, \mathrm{H}_{2} \mathrm{O}_{2}, \mathrm{OH}, \mathrm{HOCl}$, superoxide radicals and singleton oxygen (Bartosz 1996; McDonald 1999). It plays also a role in cell growth, differentiation, and metabolism. Glutathione is a tripeptide ( $\gamma$-Glu-Cys-Gly) whose reactivity is conditioned by the presence of the sulphide group -SH. Its main role is to act as an intracellular redox buffer (Bartosz 1993). It participates in sulphur metabolism, limits and protects cells against effects of oxidative stress, and takes part in detoxification of xenobiotic components (Potters et al. 2002). Both ascorbate and glutathione participate in $\mathrm{H}_{2} \mathrm{O}_{2}$ detoxification by the ascorbate-glutathione cycle (al- 
so called the Halliway-Asada pathway). This cycle is observed not only in chloroplasts (Asada 1992), but also in the cytosol, mitochondria and peroxisomes (Potters et al. 2002). It involves specific enzymes, such as ascorbate peroxidase (APO), monodehydroascorbate reductase (MR), dehydroascorbate reductase (DHAR), and glutathione reductase (GR) (Bowler et al. 1992; Foyer et al. 1994; Arrigoni 1994; Torres et al. 1997; De Gara and Tommasi 1999; de Pinto et al. 1999). The active cooperation of enzymes and high levels of low molecular antioxidants may prevent the loss of metabolic balance in cells, maintaining their redox status at a high level. In this way, the excessive production of ROS is counteracted by their increased scavenging. The aim of this study was to analyse changes in the activity of the ascorbate-glutathione cycle during storage of A. saccharinum seeds and to assess how these changes can affect the maintenance of seed viability during storage.

\section{MATERIAL AND METHODS}

\section{Plant material and viability test}

Two seedlots of silver maple (A. saccharinum L.) were collected from trees growing in the Arboretum in Kórnik (West Poland) in late May. After gathering they were immediately transferred to the laboratory and subjected to desiccation. Seeds were air dried at room temperature over the night and then packet to foil bags, sealed and kept at $3^{\circ} \mathrm{C}$ in phytotron. Their moisture content was measured in three samples of 10 seeds each, after drying at $110^{\circ} \mathrm{C}$ for $24 \mathrm{~h}$. Germination tests were conducted on two samples of 50 seeds each, on filter paper moistened with distilled water, in Petri dishes at $25^{\circ} \mathrm{C}$ in the dark.

\section{Ascorbate assays}

Ascorbic acid (ASA) and dehydroascorbate (DHA) contents were assayed according to Kampfenkel et al. (1995), using three samples of 50 embryo axes or 10 cotyledons each. The samples were homogenized in cold 6\% TCA $(\mathrm{w} / \mathrm{v})$. The homogenate was centrifuged at $12000 \mathrm{~g}$ for 20 min and the supernatant was then used.

\section{Glutatione assays}

Glutathione in the reduced (GSH) and the oxidized form (GSSG) was determined according to Smith (1985). Samples of 50 embryo axes or 10 cotyledons each were homogenized in $5 \%(\mathrm{w} / \mathrm{v})$ sulfosalicylic acid on the ice bath and then centrifuged at $10000 \mathrm{~g}$ for $20 \mathrm{~min}$.

\section{Enzyme extraction and assay}

All enzyme assays were performed in the same crude extract. All extraction procedures were carried out at $4^{\circ} \mathrm{C}$. Samples of 50 embryo axes or 10 cotyledons each were ground in liquid nitrogen and homogenized in $50 \mathrm{mM}$ sodium phosphate buffer, $\mathrm{pH} 7.0$, containing $0.2 \mathrm{mM}$ EDTA and $20 \%$ polyvinylpolypyrrolidone (PVPP) for $10 \mathrm{~min}$. Homogenates were filtered through two layers of cheesecloth and centrifuged at $4^{\circ} \mathrm{C}$ at $15000 \mathrm{~g}$ for $20 \mathrm{~min}$. Supernatant was desalted on a Sephadex G 50 column according to Helmerhorst and Stokes (1980) and was used as the crude enzyme extract.

Ascorbate peroxidase (APO, EC.1.11.1.11) activity was measured by following the decrease in absorbance at 290 $\mathrm{nm}$ due to ascorbic acid oxidation for 5-10 min, according to Nakano and Asada (1981). The reaction mixture contained: $1 \mathrm{ml}$ of $0.68 \mathrm{mM}$ ascorbic acid and $0.1 \mathrm{mM}$ EDTA in $0.1 \mathrm{M}$ phosphate buffer $\mathrm{pH} 7.0,1 \mathrm{ml}$ of $4 \mathrm{mM} \mathrm{H}_{2} \mathrm{O}_{2}$ and 50-100 $\mu 1$ of the enzyme extract. APO activity was expressed as nmol ASA min ${ }^{-1} \mathrm{mg}^{-1}$ protein.

Monodehydroascorbate reductase (MR, EC 1.6.5.4) was tested according to Zhang and Kirkham (1996). The reaction mixture contained: $50 \mathrm{mM}$ phosphate buffer $\mathrm{pH} 7.6$, $0.1 \mathrm{mM}$ NADH, $2.5 \mathrm{mM}$ ASA, 4 units of ASA oxidase and $50 \mu \mathrm{l}$ of enzyme extract. NADH oxidation was monitored at $340 \mathrm{~nm}$. MR activity was expressed as nmol NADH $\mathrm{min}^{-1} \mathrm{mg}^{-1}$ protein.

Dehydroascorbate reductase (DHAR, EC. 1.8.5.1) activity was measured according to Arrigoni et al. (1992). The reaction mixture contained: $0.9 \mathrm{ml}$ of $0.05 \mathrm{M}$ potassium phosphate buffer $\mathrm{pH} 6.3,100 \mu \mathrm{l}$ of $13.5 \mathrm{mM}$ dehydroascorbate (DHA), $100 \mathrm{ml}$ of $13.5 \mathrm{mM}$ reduced glutathione (GSH) and 100-200 $\mu$ l of enzyme extract. The DHAR activity was monitored by following the formation of ascorbate at $265 \mathrm{~nm}$ for $5 \mathrm{~min}$. Enzyme activity was expressed as nmol ASA min ${ }^{-1} \mathrm{mg}^{-1}$ protein.

Glutathione reductase (GR, EC. 1.6.4.2) activity was determined according to Esterbauer and Grill (1978), by following the rate of NADPH oxidation at $340 \mathrm{~nm}$. The assay mixture contained: $0.5 \mathrm{mM}$ NADPH, $10 \mathrm{mM}$ oxidized glutathione (GSSG), $10 \mathrm{mM}$ EDTA in $0.1 \mathrm{M}$ phosphate buffer $\mathrm{pH} 7.8$, and 50-100 $\mu \mathrm{l}$ of enzyme extract. GR activity was expressed as nmol NADPH $\mathrm{min}^{-1} \mathrm{mg}^{-1}$ protein.

Protein content of crude enzyme extracts was estimated according to Bradford (1976), using BSA as standard.

\section{Statistical analysis}

Data are presented as means \pm standard deviation of six replicates. The statistical differences between non stored control and stored seeds were tested using an analysis of variance (ANOVA). Levels of significance are indicated as $* \mathrm{P}<0.05$ and $* * \mathrm{P}<0.01$.

\section{RESULTS AND DISCUSSION}

Seeds of A. saccharinum belong to the recalcitrant category. After 6 months of storage at $+3^{\circ} \mathrm{C}$, seed viability (measured as germinability) amounted to $30 \%$ in one seed lot and $100 \%$ in the other. This difference may be due to differences in the initial moisture content, as it reached $55 \%$ in the first seed lot and 50\% in the second (Fig. 1).

Results of earlier research show that the higher is the moisture content of seeds, the faster is the loss of metabolic balance and the resultant loss of viability (Walters 1998; Walters et al. 2001; Ratajczak and Pukacka 2005). The direct cause of the viability loss in recalcitrant seeds is the oxidative stress due to the loss of metabolic balance (Sacandé et al. 2000) and excessive ROS production ( $\mathrm{Pu}$ kacka 1989, 1998; Greggains et al. 2000).

Many antioxidants, i.e. compounds combining with and removing ROS, can be found in plant cells. Among them, an important role is played by ascorbate and glutathione. During storage of both seed lots, we recorded changes in levels of those compounds. In relation to the dry weight of seeds, embryo axes contained significantly more ascorbate and glutathione than cotyledons did (Figs 2 and 3). This 


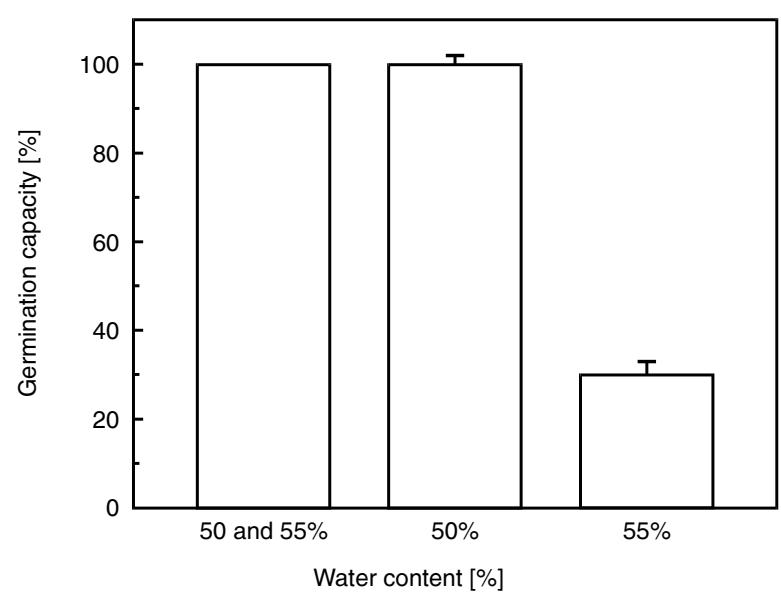

Fig. 1. Dynamics of germination of A. saccharinum seeds after shedding (50 and $55 \%$ of water content); after storage through half year and the initial moisture content of 50\%; after storage through half year and the initial moisture content of $55 \%$.

suggests that embryo axes are better equipped to withstand external disadvantageous conditions than cotyledons are. Ascorbate is represented in plant cells by a reduced form (ascorbic acid, ASA) and an oxidized form (dehydroascorbate, DHA). We found that ASA and DHA content of seeds with $100 \%$ viability did not differ significantly from the control, both in embryo axes and in cotyledons (Fig. 2). A substantial increase in both the reduced and the oxidized form was recorded in embryo axes of seeds with $30 \%$ viability (respectively from 2.1 and $1.8 \mathrm{mg} \mathrm{g}^{-1} \mathrm{DW}$ in the con-
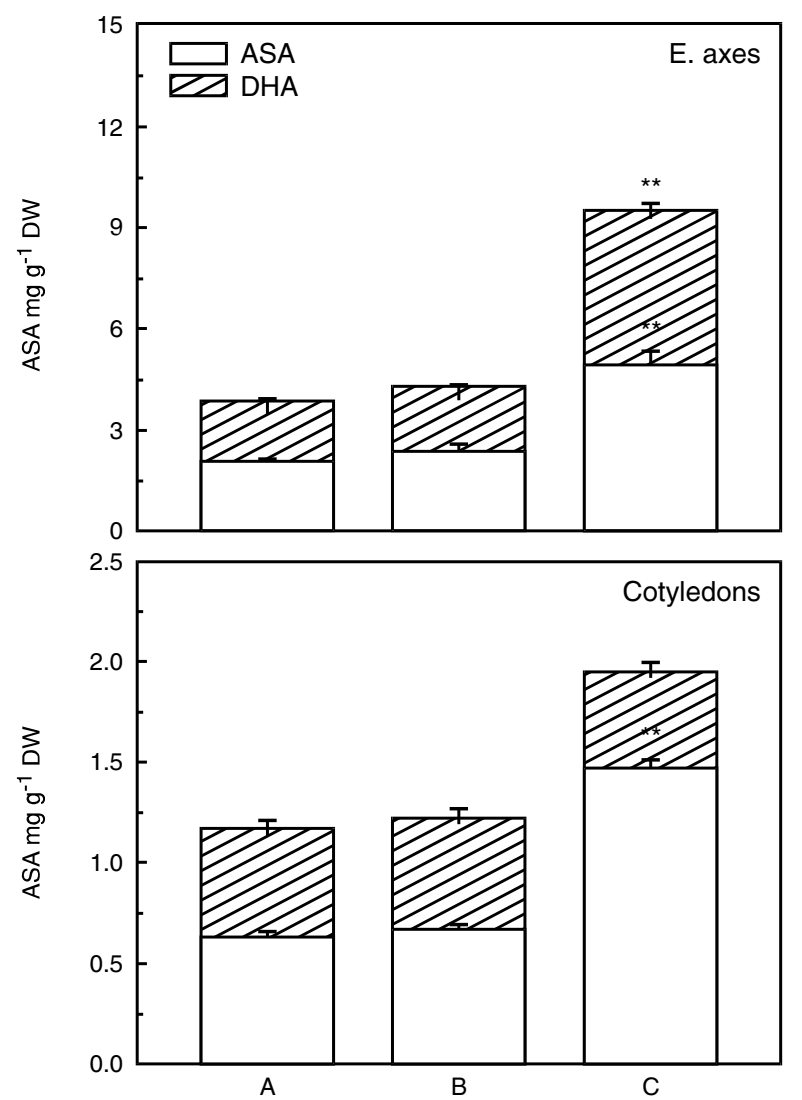

Fig. 2. Changes in ASA and DHA level in embryo axes and cotyledons of Acer saccharinum seeds after shedding (A), after storage through half year and $100 \%$ germinability (B); after storage through half year and $30 \%$ germinability $(\mathrm{C})$. trol to 4.9 and $4.6 \mathrm{mg} \mathrm{g}^{-1} \mathrm{DW}$ in stored seeds). In cotyledons of those seeds, only the ASA level increased significantly (from 0.63 to $1.5 \mathrm{mg} \mathrm{g}^{-1} \mathrm{DW}$ ). The observed increase in ASA content was a consequence of a defence reaction and could result from de novo synthesis due to more intensive respiration (Siendones et al. 1999; Millar et al. 2003) and from a low intensity of enzymatic decomposition.

In both stored seed lots, differences were also noted in levels of both the reduced (GSH) and the oxidized (GSSG) form of glutathione. In seeds of $A$. saccharinum, as in most other plant organs, the GSH content was much higher than the GSSG content. In seeds with 100\% viability, GSH and GSSG levels in embryo axes were not significantly different from the control, but in cotyledons GSH increased significantly, while GSSG decreased (respectively from 150 and $87 \mu \mathrm{g} \mathrm{g}^{-1} \mathrm{DW}$ in control to 236 and $39 \mu \mathrm{g} \mathrm{g} \mathrm{g}^{-1} \mathrm{DW}$ in stored seeds) (Fig. 3). This may attest to an oxidative stress and activation of the antioxidant system (Hsu and Sung 1997 ) in cotyledons. In seeds with $30 \%$ viability, GSH and GSSG levels decreased remarkably in embryo axes (respectively from 483 and 257 to 212 and $64 \mu \mathrm{g} \mathrm{g}^{-1} \mathrm{DW}$ ) and cotyledons (from 150 and 87 to 50 and $42 \mu \mathrm{g} \mathrm{g}{ }^{-1} \mathrm{DW}$ respectively), which indicates that both forms were used in the seed defence system in both seed parts.

In both stored seed lots, activities of nearly all the studied enzymes of ascorbate-glutathione pathway in embryo axes of seeds with $100 \%$ viability were not significantly different from the control (Fig. 4). By contrast, in embryo axes of seeds with $30 \%$ viability, enzyme activities significantly increased $(10-17 \%$ of the control). In cotyledons
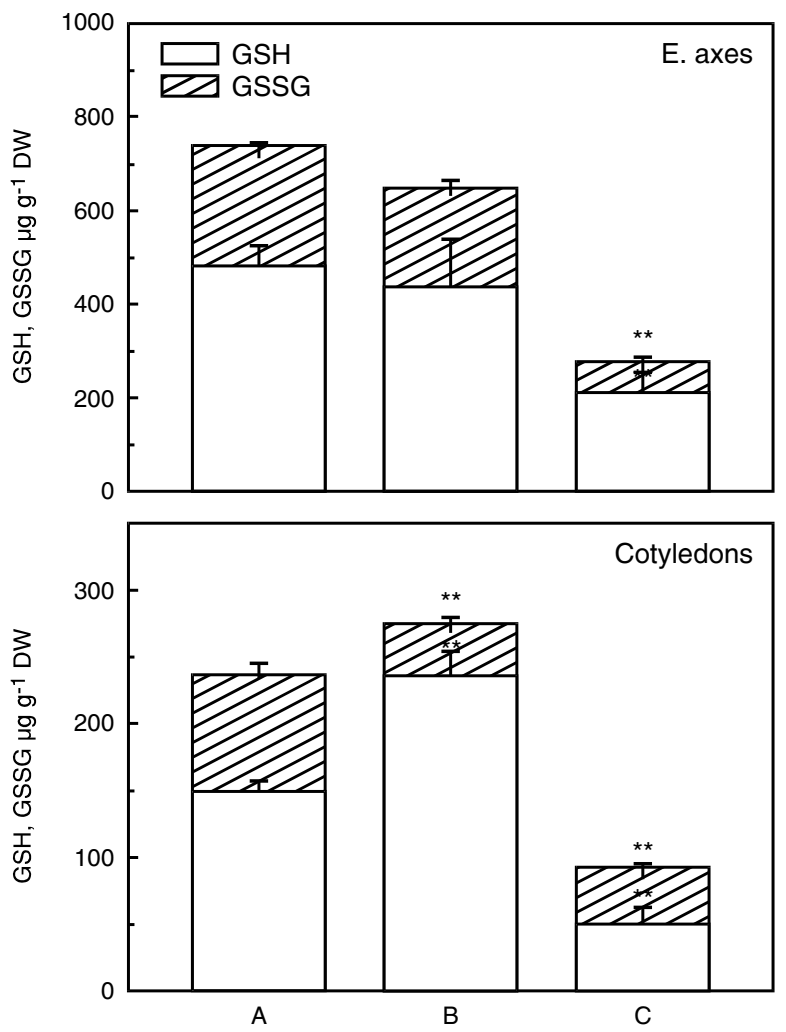

Fig. 3. Changes in GSH and GSSG level in embryo axes and cotyledons of Acer saccharinum seeds after shedding (A), after storage through half year and $100 \%$ germinability (B); after storage through half year and $30 \%$ germinability (C). 

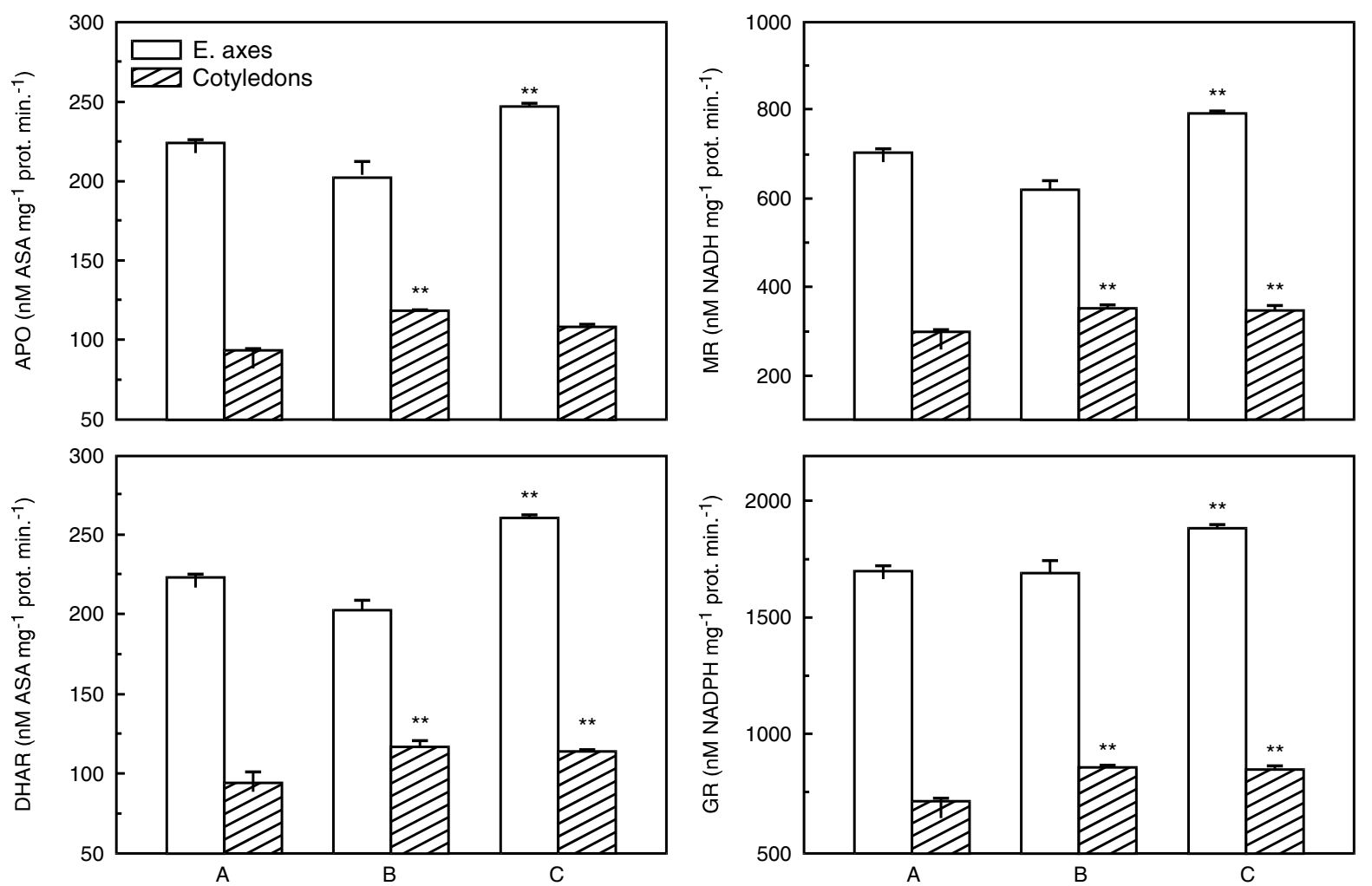

Fig. 4. Changes in activities of ascorbate peroxidase (APO), monodehydroascorbate reductase (MR), dehydroascorbate reductase (DHAR), glutathione reductase (RG) in embryo axes and cotyledons of Acer saccharinum seeds after shedding (A), after storage through half year and $100 \%$ germinability (B); after storage through half year and $30 \%$ germinability (C).

from both seed lots, activities of the studied enzymes also increased significantly in comparison with the control (18$-26 \%$ ) (Fig. 4).

Interestingly, MR and GR activities in embryo axes of seeds with $30 \%$ viability increased and were accompanied by a slight increase in APO and DHAR activities. MR and GR participate in recycling of the two low molecular antioxidants (ascorbate and glutathione, respectively), so the observed increase in their activity in embryo axes of seeds with $30 \%$ viability reflects their increased sensitivity to storage conditions and activation of defence reactions.

Results of this study indicate that the viability of the two seed lots of A. saccharinum during storage was significantly affected by their moisture content. Seeds with $100 \%$ viability did not show clear symptoms of oxidative stress in embryo axes, as the activity of the ascorbate-glutathione cycle changed only slightly there. However, some changes were recorded in their cotyledons (Figs 3 and 4). In seeds with $30 \%$ viability, significant changes in the whole antioxidant system were noted both in embryo axes and in cotyledons. This attests to oxidative stress, which caused the loss of viability of the stored seeds.

\section{LITERATURE CITED}

ARRIGONI O., DE GARA L., TOMMASI F., LISO R. 1992. Changes in the ascorbate system during seed development in Vicia faba. Plant Physiol. 99: 235-238.

ARRIGONI O. 1994. Ascorbate system in plant development. J. Bioenergetics and Biomembranes 26: 407-419.

ASADA K. 1992. Production and scavenging of oxygen in chloroplast. Molecular biology of free radical scavenging systems.
Scandalios J.G. (ed.), Cold Spring Harbor Laboratory Press, Cold Spring Harbor: 173-192.

BAILLY C., BENAMAR A., CORBINEAU F., CÔME D. 1998. Free radical scavenging as affected by accelerated ageing and subsequent priming in sunflower seeds. Physiol. Plant. 104: 646-652.

BARTOSZ G. 1993. Glutathione metabolism. Postępy Bioch. 39: 33-38.

BARTOSZ G. 1996. Peroxynitrice: mediator of the toxic action of nitric oxide. Acta Biochim. Pol. 43: 645-660.

BOWLER C., VAN MONTAGU M., INZÉ D. 1992. Superoxide dismutase and stress tolerance. Ann. Rev. Plant Physiol. Plant Mol. Biol. 43: 83-116.

BRADFORD M.M. 1976. A rapid and sensitive method for the quantitation of microgram quantities of protein utilizing the principle of protein-dye binding. Anal. Bioch. 72: 248-254.

DE GARA L., TOMMASI F. 1999. Ascorbate redox enzymes: a network of reaction involved in plant development. Recent Research Development in Phytochemistry 3: 1-15.

DE PINTO M.C., TOMMASI F., DE GARA L. 1999. The redox state of ascorbate-dehydroascorbate pair as a specific sensor of cell division in tobacco TBY-2 cells. Protoplasma 209: 90-97.

ESTERBAUER H., GRILL D. 1978. Seasonal variation of gluthathione and gluthatione reductase in needles of Picea abies. Plant Physiol. 62: 119-121.

FOYER C., LELANDIAS M., KUNERT K.J. 1994. Photooxidative stress in plants. Physiol. Plant. 92: 696-717.

GREGGAINS V., FINCH_SAVAGE W.E., QUICK P., ATHERTON N.M. 2000. Metabolism-induced free radical activity does not contribute significantly to loss of viability in moist-stored recalcitrant seeds of contrasting species. New Phytol.148: 267-276.

HELMERHORST E., STOKES G.B. 1980. Microcentrifuge desalting: a rapid quantitative method for desalting small amounts of protein. Anal. Bioch. 104: 130-135. 
HENDRY G.A.F. 1993. Oxygen, free radical processes and seed longevity. Seed Sci. Res. 3: 141-153.

HSU J.L., SUNG J.M. 1997. Antioxidant role of glutathione with accelerated aging and hydration of triploid watermelon seeds. Physiol. Plant. 100: 967-974.

KAMPFENKEL K., VAN MOTAGU M., INZÉ D. 1995. Extraction and determination of ascorbate and dehydroascorbate from plant tissue. Anal. Bioch. 225: 165-167.

McDONALD M.B. 1999. Seed deterioration: physiology, repair and assessment. Seed Sci. Technol. 27: 177-237.

MILLAR A.H., MITOVA V., KIDDLA G., HEAZLEWOOD J.L., BARTOLI C.G., THEDODOULOU F.L., FOYER C. 2003. Control of ascorbate synthesis by respiration and its implications for stress responses. Plant Physiol. 133: 443-447.

NAKANO Y., ASADA K. 1981. Hydrogen peroxide is scavenged by ascorbate - specific peroxidase in spinach chloroplast. Plant Cell Physiol. 22: 867-880.

POTTERS G., DE GARA L., ASARD H., HOREMANS N. 2002. Ascorbate and glutathione: guardians of the cycle, partners in crime? Plant Physiol. Bioch. 40: 537-548.

PRIESTLEY D.A. 1986. Morphological, structural and biochemical changes associated with seed aging. In: Seed Aging. Implications for Seed Storage and Persistence in the Soil. Priestley D.A. (ed.), pp. 125-193. Cornell University Press, Ithaca, NY.

PUKACKA S. 1989 The effect of desiccation on viability and phospholipid composition of Acer saccharinum L. seeds. Trees 3: $144-148$.

PUKACKA S. 1998. Changes in membrane fatty acid composition during desiccation of seeds of silver maple. Seed Sci. Technol. 26: 535-540.

RATAJCZAK E., PUKACKA S. 2005. Decrease in beech (Fagus sylvatica) seed viability caused by temperature and humidity conditions as related to membrane damage and lipid composition. Acta Pysiol. Plant. 27: 3-12.
SACANDÉ M., HOEKSTRA F.A., VAN AELST A.C., de VOS C.H.R. 2000. Is oxidative stress involved in the loss of neem (Azadirachta indica) seed viability? Seed Sci. Res. 10: 381-392 .

SIENDONES E., GONZALEZ-REYES J.A., SANTOS-OCANA C., NAVAS P., CORDÔBA F. 1999. Biosynthesis of ascorbic acid in kidney bean. L-galactono- $\gamma$-lactone dehydrogenase is an intrinsic protein located at the mitochondrial inner membrane. Plant Physiol. 120: 907-912.

SUSZKA B., MULLER C., BONNET-MASIMBERT M. 2000. Seeds of forest broadleaves - from harvest to sowing. Advances in Science PWN, Warszawa, pp. 145-152.

SMITH I.K. 1985. Stimulation of glutathione synthesis in photorespiring plants by catalase inhibitors. Plant Physiol. 79: 044$-1047$.

SMITH M.T., BERJAK P. 1995. Deteriorative changes associated with the loss of viability of stored desiccation-tolerant and desiccation-sensitive seeds. In: Seed Development and Germination Kigel J., Galili G., (eds). Marcel Dekker, Inc., New York, NY. pp. 701-746.

TORRES M., DE PAULA M., PÉREZ-OTAOLA M., DARDER M., FRUTOS G., MARTINEZ-HONDUVILLA C.J. 1997. Ageing-induced changes in glutathione system of sunflower seeds. Physiol. Plant. 101: 807-814.

WALTERS C. 1998. Understanding the mechanisms and kinetics of seed ageing. Seed Sci. Res. 8: 223-244.

WALTERS C., PAMMENTER N.W., BERJAK P., CRANE J. 2001. Desiccation damage, accelerated ageing and respiration in desiccation tolerant and sensitive seeds. Seed Sci. Res. 11: 135-148.

ZHANG J., KIRKHAM M.B. 1996. Enzymatic response of the ascorbate-glutathione cycle to drought in sorghum and sunflower plants. Plant Sci. 113: 139-147. 